\title{
THE SIGNIFICANCE OF THE VAN TILLIAN METHOD IN APOLOGETICS WITH AN EXAMPLE OF ARGUMENT TO MUSLIMS
}

\author{
Muriwali Yanto Matalu \\ Gerakan Kebangunan Kristen Reformed (GKKR) \& \\ Gereja-Gereja Reformasi di Indonesia (GGRI)
}

\begin{abstract}
Presuppositional apologetics has become a main alternative (or competitor?) for the classical apologetics which maintains evidences. Although its emergence occurred within the Reformed tradition, particularly through the effort of Cornelius Van Til and Gordon Clark, its significance goes beyond the Reformed tradition. Even the contemporary evangelical apologist, Ravi Zacharias, also utilizes presuppositional apologetics which he combines with evidentialistic method. This fact is hardly denied when we read his book "Jesus among Other Gods." Thus, the main concern of this article is regarding the significance of the presuppositional apologetics particularly in its Van Tillian form. After presenting an exposition on this method, we will see its application toward Muslims' concept of God and the idea of uniformity.
\end{abstract}

KEYWORDS: Presuppositional apologetics, Van Til, antithesis, one and many, reasoning by presupposition, reductio ad absurdum, Islam.

ABSTRAK: Apologetika Presupossional telah menjadi alternatif utama (atau pesaing?) bagi apologetika klassik yang memakai bukti-bukti. Sekalipun munculnya apologetika ini terjadi di tradisi Reformed, khususnya melalui upaya Cornelius Van Til dan Gordon Clark, tapi pentingnya melampaui batasan tradisi Reformed. Bahkan apologet injili kontemporer, Ravi Zacharias, juga menggunakan apologetika presuposisional yang dia 
kombinasikan dengan metode pembuktian. Fakta ini sulit dibantah jika kita membaca karangannya "Yesus diantara para allah." Maka, perhatian utama dari artikel ini adalah mengenai pentingnya apologetika presuposisinal secara khusus dalam bentuk Van Tillian. Setelah mengemukakan eksposisi akan metode ini, kita akan melihat aplikasinya terhadap konsep Muslim akan Allah dan ide mengenai keseragaman.

KATA KUNCI: Apologetika Presuposisional, Van Til, antithesis, satu dan banyak, berargumen dengan presuposisi, reductio ad absurdum, Islam.

\section{Introduction}

In the Indonesian context, when the reformation era which has been started since 1998 following the end of the dictatorship government of President Soeharto, the real democratic life of the nation gained its ground. In this sense, Indonesian people have more freedom to express their convictions and opinions publicly and it is protected by laws. In the religious context, many leaders and thinkers, particularly from Islam, hold public debate events with other religious' thinkers especially from Christian. I myself had ever been invited by an Islam foundation to participate in a public debate. The subject was "Tawhid or Trinity?" I came with one Christian apologist and facing two Muslims apologists.

As I noticed, my Christian friend used evidentialistic method (a common method among Indonesian Christian apologists) which stresses on evidences and the result was an endless debate with the Muslim speakers around the verses of the Bible and the Quran. ${ }^{1}$ Indeed, this method presupposes the neutrality of human reason and therefore both parties that

\footnotetext{
1 To say that disputing the verses of the Bible and the Quran when a Christian apologist debates with a Muslim as using evidentialistic method is probably a generalization. However, the reason I conclude that my Christian friend used evidentialistic method because both he and the Muslim speakers assumed the neutrality of human reason as a base to judge those verses.
} 
are involved can refer to the verses of both the Bible and the Quran as if Christians understand the Quran as Muslims understand it and Muslims understand the Bible as Christians understand it. I myself do not favor this method and prefer to use the Van Tillian presuppositional method ${ }^{2}$ because it presupposes an antithesis between Christian and non-Christian. According to this antithesis, there is no neutrality or common ground between them and therefore in a debate the participants could not directly refer to the law and fact. For instance, when they arguing the fact about God, the Christian will refer to the Trinity while the Muslim point to a Unitarian God.

Indeed, the Muslim apologists during the debate could not give an adequate response to my arguments either because they could not understand for those arguments were new for them or because they have nothing to do with them. For example, when I reduce their idea of God to unintelligible, ${ }^{3}$ regarding the difficulty of this God to actualize love relationship etc., they did not deal with this argument at all. ${ }^{4}$

Taking this as a background, the purpose of this paper is to analyze the significance of the presuppositional apologetics as promoted by Cornelius Van Til and tries to apply it to Muslims' worldview. The main research question: What is the significance of the Van Tillian presuppositional apologetics in defending the Christian faith? In order to get an adequate answer to this question, first, an exposition on Van Til method will be described, and second, presenting an example of argument toward Muslims' idea of God and their uniformity view will be a nice closing (conclusion).

\footnotetext{
2 In doing apologetics, to consider myself as a Van Tillian is probably true in its most part.

3 Reducing someone's view to unintelligible (reductio ad absurdum) is one of the characteristics of the Van Tillian method.

4 Someone has uploaded the complete debate in youtube and whoever could understand Indonesian will know that the Muslim speakers did not touch at all the core of my arguments. See the video here: https://www.youtube.com/watch?v=sX1ifOWzEu0 (accessed July 12 2016).
} 


\section{An Exposition on Van Tillian Presupositional Apologetics}

Frame argues that denoting Van Til as a presuppositionalist is sometimes misleading because if the term means "apriorism" he is not a presuppositionalist. ${ }^{5}$ Yet in some sense, according to Frame, Van Til may be called as a presuppositionalist by considering his conviction in the revelation of God as has absolute authority and therefore has a certain priority over all human thought. ${ }^{6}$ Moreover, Van Til views the revelation as human ultimate criterion of truth in all areas of life. ${ }^{7}$ Indeed, revelation governs our interpretation of experience which is one traditional function of a priori knowledge. But we discover it partly through experience, for instance, we learn about God by reading the Bible lead by the Holy Spirit's illumination and by observing God's handiwork in creation and in ourselves, and therefore, it is unlike a priori knowledge in the traditional sense in philosophy. ${ }^{8}$ In spite of Frame's opinion, Van Til has become well known as an apologist who champions the presuppositionalism method. For instance, Sproul argues, "Cornelius Van Til is, without doubt, the leading exponent of presuppositionalism. Van Tillianism is almost a synonym for presuppositionalism, though the school is much broader than any one thinker." 9

Van Til himself defines apologetics as "the vindication of the Christian philosophy of life against the various forms of the non-Christian philosophy of life." 10 Therefore, according to him, in defending the Christian faith, believers have to defend it as a whole or as a unit and not partially. ${ }^{11}$

\footnotetext{
5 John M. Frame, Cornelius Van Til: An Analysis of His Thought (Phillipsburg: P\&R, 1995), 135.

6 Ibid.

7 Ibid.

8 Ibid.

9 R.C. Sproul, John Gerstner, Arthur Lindsley, Classical Apologetics (Grand Rapids: Zondervan, 1984), 183.

10 Cornelius Van Til, Christian Apologetics, William Edgar, ed. (Phillipsburg: P\&R, 2003), 17.

11 Ibid., 18. See also p. 149.
} 
Moreover, if Christians are to defend Christian theism as a unit it must be shown that its part are really related to one another. ${ }^{12}$ Because Van Till argues that believers must defend the Christian theism as a unit then he comes to the conclusion that in the systematic theology we have the system of truth in which we defend. He describes, "... systematic theology is more closely related to apologetics than are any of the other disciplines. In it we have the system of truth that we are to defend."13 Also, in his view, the Christian theism as a unit (systematic theology) is a salient feature of the Christian life and world-view. It presents itself as an absolute comprehensive interpretation of human experience, and indeed, it is also the only true interpretation of human experience. ${ }^{14}$ Therefore, we can conclude that in his system, doing apologetics is to bring the Christian worldview in the battle field to compete with other worldviews. The following discussion will elaborate three among many important points in Van Til's thought which are relevant to our farther discussion.

\section{Antithesis Between Believers and Unbelievers}

Van Til believes that human mind is not neutral, it is either serves God's truth or Satan, God's righteousness or sin. In this sense, he maintains the antithesis between believer and non-believer and indeed echoing Kuyper's antithesis. Rushdoony is correct when he calls Van Til as a prominent and leading member of the Kuyperian's school. ${ }^{15}$ Regarding the antithesis, Kuyper believes that the regenerated are in absolute antithesis with the un-regenerated. ${ }^{16}$ This antithesis is implicitly stated when he

\footnotetext{
12 Ibid., 19.

13 Ibid., 23.

14 Ibid., 83.

15 Rousas John Rushdoony, Van Til (Phillipsburg: P\&R, 1979), 15.

16 However, Kuyper also stresses on the common grace in a significant manner. Indeed, it is a difficult task to make a connection between the common grace which proposes a common ground between believers and non-believers and the antithesis which maintains a gulf between them. Tim McConnel tries to see their connection in Kuyper's idea of "sphere sovereignty," for
} 
speaks about the war between Christianity and modernism in his "Lecture on Calvinism":

There is no doubt then that Christianity is imperiled by great and serious danger. Two life-system are wrestling with one another, in mortal combat. Modernism is bound to build a world of its own from the data of the natural man and to construct man himself from the data of nature; while on the other hand, all those who reverently bend the knee to Christ and worship Him as the Son of the living God, and God himself, are bent upon saving "the Christian Heritage"17 (italics of the word "natural man" is from me).

No doubt, the term "natural man" used by Kuyper here denotes unregenerated, which is also used by Van Til, for instance, he uses this term when he argues that the natural man is impossible to interpret the natural (common) revelation, and suppose he can correctly interpret it then the special revelation in Christianity loses its significance to him. ${ }^{18}$ In this sense, Van Til rejects the unbelievers as able to understand the truth of God's general revelation, and indeed, they will need to be regenerated in order to understand it. Therefore, in epistemology, he rejects common ground between Christian and non-Christian. He argues, "It will be quite impossible, then, to find a common area of knowledge between believers and unbelievers unless there is agreement between them as to the nature of man himself. But there is no such agreement."19

instance he says, "Abraham Kuyper's most enduring legacy has been in the realm of theology, and particularly in his attempt to take account of both common grace and the antithesis. The former provided a basis for unity and cooperation in the cultural task while the later maintained a sharp distinction and even a cleavage. Kuyper held this tension in balance consistently throughout his career, as can be seen in his 1880 speech on 'Sphere Sovereignty.'" See Tim McConnel, "Common Grace or the Antithesis?: Towards a Consistent Understanding of Kuyper's 'Sphere Sovereignty,'” Pro Rege - September 2002: 9-10.

17 Abraham Kuyper, Lecture on Calvinism (Grand Rapids: Eerdmans, 2002), 11.

18 Van Til, Christian Apologetics, 111.

19 Ibid., 84. 
Van Til rejects the method of Thomas Aquinas and Bishop Butler who establish a neutral principle of coherence or rationality, and also refuses the method of Gordon Clark ${ }^{20}$ and Edward Carnell who emphasize the law of non-contradiction. The problem of their method, according to Van Til, first, if the law or principle is the basic tool for understanding, then God has no significance in our thinking and interpretation. Second, this method allows the natural man to interpret certain facts correctly although he is a covenant breaker but indeed he cannot interpret facts correctly because he wears the colored spectacles of the covenant breaker. ${ }^{21}$

To elaborate this, Van Tils's evaluation to Aquinas' position could be an example. Indeed, Aquinas insists a neutral principle of coherence. For instance, after stating that human could prove the existence of God he argues, "Having shown then that it is not futile to endeavor to prove the existence of God, we may proceed to set forth the reasons whereby both philosophers and Catholic doctors have proved that there is a God"22 (Italics by me). It is clear here that he and the philosophers are in the same line of reasoning (in a neutral reason) and try to prove the existence of a God (a neutral God). Then he proceeds to quote Aristotle and borrowing this Greek philosopher's argument which insists that movement in the universe is irrational or impossible until we maintain that there is an immovable mover. ${ }^{23}$ Again, we see here that this argument is not pointing to the Trinity but to the immovable mover as a neutral God. In this sense, Van Til is correct when he says that Aquinas tried to defend the truth of Church doctrines by

20 Gordon Clark is a presuppostionalist who stresses on the law of non-contradiction as a judge between believers and non-believers, while Van Til is a presuppositionalist who presupposes the God of the Bible as the ultimate point of reference. There was a polemic between them about the theory of knowledge especially the relation between God's knowledge and human's, see Frame, Cornelius Van Til, 97-113.

21 Rushdoony, Van Til, 19.

22 St. Thomas Aquinas, The Summa Contra Gentiles: The First Book (New York: Aquin Media, 2010) Kindle Electronic Edition, 13.

23 Ibid. 
employing the Aristotelian methods of reasoning. ${ }^{24}$ And for this reason, he charges Aquinas and the like-minded scholastics ${ }^{25}$ as had not yet sensed the depth of the antithesis between the theistic and the antitheistic motive. ${ }^{26}$ Moreover, he states, "If the Christian doctrine of the Trinity had really sunk into the consciousness of the teachers of the church it would have been impossible for them to have turned again to the fleshpots of Egypt."27 By stating this, Van Til maintains the antithesis between believers and nonbelievers and its result is the absurdity of the neutral principle of coherence.

Therefore, for Van Til, believers cannot make reason and evidences as the base of Christian apologetics, and on the contrary, Christians have to start with God and end with God. He argues, "The only 'proof' of the Christian position is that unless its truth is presupposed there is no possibility of 'proving' anything at all." 28 Additionally, we can call the classical method of Aquinas, Butler, and today, R. C. Sproul, 29 as evidentialistic because it basically stresses on evidences.

\section{The Principle of One and Many}

Van Til is known for his discourse of the problem of one and many (unity and plurality) ${ }^{30}$ which was a matter of philosophy for long time. The term many or plurality here does not mean anything plurality, for instance,

24 Cornelius Van Til, A Survey of Christian Epistemology: Volume 2 of the series in Defense of Biblical Christianity (Phillipsburg: P\&R, 1969), Kindle Electronic Edition: Chapter 5, Location 55.

25 Van Til clearly distinguishes between the scholastics who have a tendency to Augustinian and those who have Aristotelian tendency. Anselm is an example for the first tendency, and Abelard as well as Aquinas are examples for the second, see Van Til, A Survey, Location 55.

26 Ibid., Location 56.

27 Ibid.

28 Cornelius Van Til, "My Credo" in Jerusalem and Athens: Critical Discussion on the Philosophy and Apologetics of Cornelius Van Til, E. R. Geehan, ed. (Phillipsburg: P\&R, 1971), 21.

29 The "Classical Apologetics" of R. C. Sproul, John Gerstner, and Arthur Lindsley is a defense on classical and evidentialistic method as well as a critique to Van Tillian presuppositionalism.

30 Cf. Frame, Cornelius Van Til, 71. 
it is not a plurality in sexual orientations consist of heterosexual, gay, lesbian, polygamy, polyandry and so on. To make this term clear, I borrow the definition of Mouw and Griffioen on pluralism. They divide pluralism into three categories: first, directional pluralism which is related to the different visions of the good life that gives direction to people's life. Religions and also some value orientations like hedonism and Marxism are included in this category. Second, associational pluralism such as family or clubs and association. Third, contextual pluralism, for instance, different ethnic, race, geographic, gender, and so on. ${ }^{31}$ The first category is probably not relevant for discussing Van Til because he views the term many in its metaphysical and cosmological aspects and therefore excludes the plurality of value orientations (e.g. Christianity, Atheism, Hedonism, Marxism etc. or between good things and evils). There are two reasons to exclude this first category: 1) The ultimate base of the concept of one and many in Van Til's idea is the Trinity. It is a metaphysical one and many and indeed it is a glorious and excellent one and many which excludes all evils and imperfections. Thus, his main concern is to offer a solution for the metaphysical and cosmological problems of the one and many in philosophy which he found in the doctrine of the Trinity. 2) His idea of antithesis will view the plurality of value orientations as false, because according to this term (antithesis), the only true ethical value is only in the Christian Bible. Suppose the plurality of value orientations is included, we will only find the element of plurality without unity, because Christian and non-Christian values will never become one (unity). Nevertheless, the second and the third categories are relevant to our discussion on Van Til's concept of one and many.

The problem of one and many had become a philosophical debate since the age of Thales, for instance he argues that the substance of the world

31 Richard Mouw, Sander Griffioen, Pluralism and Horizons: An Essay in Christian Public Philosophy (Grand Rapids: Eerdmans, 1993), 16-17. 
is water ${ }^{32}$ and therefore stresses on unity. Parmenides, maintains unity when he argues that the existence is only one, while Heraclitus rejects this idea when he says that all sensible things are always in a state of flux. ${ }^{33}$ Modernism which tries to find an absolute truth indeed focuses on unity while postmodernism today which sees truth as relative stresses on diversity. ${ }^{34}$ Van Til make a summary on this problem:

In seeking for an answer to the one and many question, philosophers have admittedly experienced great difficulty. The many must be brought into contact with one another. But how do we know that they can be brought into contact with one another? How do we know that the many do not simply exist as unrelated particulars? The answer given is that in such a case we should know nothing of them; they would be abstracted from the body of knowledge that we have; they would be abstract particulars. On the other hand, how is it possible that we should obtain a unity that does not destroy the particulars? We seem to get our unity by generalizing, by abstracting from the particulars in order to include them into larger unities. If we keep up this process of generalization till we exclude all particulars, granted they can all be excluded, have we then not stripped these particulars of their particularity? Have we then obtained anything but an abstract universal? ${ }^{35}$

To elaborate what Van Til is trying to say here, Frame's explication on this is probably helpful. I try to explain his illustration using my own words. If we see dogs such as Fido, Rover, and Spot, we classify them into a dog group which have significance similarities among them and have significance differences with other type of animals. Then we try to find the essence of Fido, for example, we call Fido as a dog and by doing this we are designating his essence (what he really is). However, the dogs still can be classified into larger classes such as canines, mammals, living beings, beings,

32 See Aristotle, "Metaphysics, Book I (A)," in The Complete Works of Aristotle Vol. II, W. D. Ross, trans., Jonathan Barnes ed. (Princeton: Princeton University Press, 1991), Kindle Electronic Edition, 7.

33 Ibid., 12-13.

34 Cf. Mouw, Griffioen, Pluralism and Horizons, 91-92.

35 Cornelius Van Til, The Defense of the Faith (Phillipsburg: P\&R, 1967), 25-26. 
and being. This is a process of abstraction from the lesser classes to "being in general." Indeed, Fido is more than being or beings or living being or even a dog. He has feet, color, walking and playing ball and none of these abstracting processes say something about the real properties of Fido. These abstractions just make Fido an empty thing and not real. ${ }^{36}$ We can call this abstract unity. Here Frame tries to explain that the philosophers' effort to find essence by making a unity through the process of abstraction only comes to nothing or mere abstraction. Then Frame tries to show the absurdity of the other philosophers who try to find the essence of a thing by emphasizing plurality (the many), namely, it goes from general to particular. For example from being to beings, living beings, mammals, then to dogs and finally we come to Fido. Let us try to find the essence of Fido by taking one of his parts, for example, his kidney, yet his kidney still has many parts and then we try to take one part of his kidney and so on to find his essence. Frame argues that even if we can find the "ultimate matter" (the part which cannot be divided again) through this process, the "ultimate matter" itself informs nothing about Fido. It is also an abstraction. ${ }^{37}$ Then he concludes, "In the end, there is no difference between 'being in general' and 'ultimate matter.' Both concepts are empty, uninformative, and unintelligible. And if the real essence of everything, the real truth about the world, is to be found in either of these concept, then the world is completely devoid of intelligible meaning." 38

Perhaps Plato's concept of the ideas could reflect Frame's phrase, "the world is completely devoid of intelligible meaning." Plato argues that whenever a plurality of individuals have a common name, they have also a corresponding idea or form. ${ }^{39}$ This is the universal or the common nature

\footnotetext{
36 Frame, Cornelius Van Til, 72.

37 Ibid., 72-4.

38 Ibid., 74.

39 Frederick Copleston, S.J., A History of Philosophy, Vol.1: Greece and Rome (New York: Doubleday, 1993), Kindle Electronic Edition, 164.
} 
which is grasped in the concept, for instance, beauty.40 On this, Copleston explains, "There are many beautiful things, but we form one universal concept of beauty itself: and Plato assumed that these universal concepts are not merely subjective concepts, but that in them we apprehend objective essences." 41 This principle is not only for the moral and aesthetical universals but also Plato applies it to the natural objects like man or horse. ${ }^{42}$ Yet the problem here is that the idea of beauty itself is nothing till one applies it to a certain object or moral quality, for instance, a beauty flower or a beauty attitude. This is also true for the natural objects like horse. The idea of horse (or the horse-ness) is an empty idea till it points to a certain individual horse. In this sense, Plato's concept of ideas is no more than abstract universals. The Indian greatest philosopher, Shankara, falls into the same pit with Plato, when he arguing that in order to understand God (Brahman), all attributes (particularities) could not be applied to him and therefore he proposing a nirguna Brahman (Brahman without attributes), ${ }^{43}$ although at the same time he says that we could only speak about Brahman as has attributes for the importance of devotions. ${ }^{44}$ The reason according to Shankara, when people argue that God has determinations, personality, perfection (guna; attributes), it is complicated to understand how these characteristics coexist with the absoluteness (Brahman). ${ }^{45}$ However, by

\footnotetext{
$40 \quad$ Ibid.

41 Ibid.

42 Ibid.

43 See Sri Shankaracharya, Brahma Sutra Bhasya of Sri Shankaracharya, Swami Gambhirananda, trans. (Kolkata: Swami Mumukshananda, 2004), Kindle Electronic Edition: Chapter Three, Section II, Location 1208.

44 Ibid. Indeed, Shankara does not believe that Brahman really has attributes, yet according to him, to make our devotions to Brahman intelligible then denoting attributes to him is necessary, Cf. Gavin Flood, An Introduction to Hinduism (New York: Cambridge University Press, 1996), 238. Also, Kshiti Mohan Sen, Hinduism (Harmondsworth: Penguin Books, 1961), 242

45 See S. Radhakrishnan, Indian Philosophy, Vol. 2 (New Delhi: Oxford University Press, 2008), 507.
} 
stripping all of his particularities, Brahman is no more than an empty universal.

Indeed, Van Til rejects such notions by proclaiming the concept of one and many in the Trinity. According to him, the solution for the problem of one and many only exists in the doctrine of the Trinity. In it we really find a concrete universal because it is not mere a being in general or an abstract unity but the real being of God, in which all particulars relate to the universal and the universal is fully expressed in the particulars. ${ }^{46}$ In other words, in the Trinity the concept of one does not exist as an abstract universal as philosophers view it (e.g. Plato, Shankara, or modernism's concept on universal truth) but in the real being of God and therefore we find a concrete universal. Moreover, the being of God is fully expressed in its particulars (in the three persons) and therefore the particulars are not just ultimate matters or abstract particulars. Consequently, Christians really have a concrete one and many in the being and the persons of God.

\section{Reasoning by Presupposition (Transcendental Argument)}

The Van Tillian presuppositional method has significance difference from the evidentialistic/classical method, where the latter uses reason and evidences as its main base. For instance, to prove the existence of God, evidentialistic/classical apologists utilize the ontological, cosmological, teleological, moral, and historical/ethnological arguments. Aquinas is well known for his cosmological and teleological arguments. ${ }^{47}$

Rather than maintaining reason and evidences as its base, Val Til offers a method which he calls as reasoning by presupposition (transcendental argument). He says that arguing by presupposition is to

46 Cornelius Van Til, The Defense of the Faith, 26.

47 For a brief study on these arguments, see Louis Berkhof, Systematic Theology: New Combined Edition (Grand Rapids: Eerdmans, 1996), 26-8. However, Berkhof himself does not favor these arguments for apologetics although he admits that they have a valuable meaning for believers. 
indicate the epistemological and metaphysical principles that underlie and control one's method. ${ }^{48}$ To elaborate this: 1 ) It is indirect method rather than direct because the issue between believers and nonbelievers in Christian theism cannot be settled by a direct appeal to "facts" and "laws" whose nature and significance is already agreed by both parties. ${ }^{49}$ I try to elaborate what Van Til means on this. Because there is an absolute antithesis between believers and nonbelievers, then for him, the both parties cannot refer directly to the facts and laws in a debate for a certain issue/case. In the early of his "Christian Apologetics," he argues that it is impossible and useless to vindicate Christianity as a historical religion by a discussion of facts only. ${ }^{50}$ He proceeds to give an example:

Suppose we assert that Christ arose from the grave. We assert further that his resurrection proves his divinity. This is the nerve of the "historical argument" for Christianity. Yet a pragmatic philosopher will refuse to follow this line of reasoning. Granted he allows that Christ actually arose from the grave, he will say that this proves nothing more than that something very unusual took place in the case of "that man Jesus." 51

Therefore, according to Van Til, this war is not about a certain issue (e.g. the resurrection of Christ) and to seek whose fact on the issue is right or wrong, but it is a battle between worldviews and if the Christian worldview (e.g. epistemology and metaphysic) is true and meaningful, then the fact about the resurrection must be true and meaningful.

2) Van Til does not reject proofs and evidences which are used by the classical/evidential apologists but he wants to utilize proofs and evidences in the corridor of the Christian presupposition. In the very beginning of his "Christian Apologetics," he clearly distinguishes between defending

48 Van Til, Christian Apologetics, 128.

49 Ibid., 129.

50 Ibid., 18.

51 Ibid. 
Christianity as a historical religion which largely speaks about evidences and defending theism as a philosophical argument upon which Christianity is based. ${ }^{52}$ However, according to him, in apologetics, we deal almost with the philosophical argument under the protection of which the definite advances in the historical field must be made. ${ }^{53}$ Thus in this respect, he proposes a philosophical discussion which defends Christianity as a unit through the protection of the evidences in the historical field. Precisely, here is the place and the significance of the evidences. Moreover, the relation between evidences and apologetics is clearly defined by Van Til. He argues, "Evidences deals largely with the historical while apologetics deals largely with the philosophical aspect. Each has its own work to do but they should constantly be in touch with one another." 54 Additionally, because apologetics deals with the philosophical argument, thus in his system, proofs and evidences could be reduced to one main proof, namely, "unless this God, the God of the Bible, the ultimate being, the Creator, the controller of the universe, be presupposed as the foundation of human experience, this experience operates in a void." 55 As a conclusion, one perhaps may use, for instance, the cosmological argument, but this argument cannot be utilized without presupposing the God of the Bible. In this sense Van Til is correct, because starting the cosmological argument just from an analysis of the movement (or cause and effect) in the universe and then comes to the conclusion that there must be an unmoved mover (or a prime cause) will lead nowhere to the Christian God. But when we start by presupposing the Christian God and placing the cosmological argument in this corridor, it is more convincing. For Van Til, if we start from the God of the Bible, we will also end with this God and otherwise will bring us nowhere.

52 Ibid., 19.

53 Ibid.

54 Ibid.

55 Frame, Cornelius Van Til, 313. 
3) To apply this method, according to Van Til, the Christian apologists must place themselves upon the opponent's position and assuming the correctness of his method merely for argument's sake, in order to show him that in such position the facts are not facts and the laws are not laws. ${ }^{56}$ So according to this method, we have to listen to our opponent's view and try to place ourselves on that position in order to tell him that such position speaks nothing about facts and laws. Then we present our own Christian view and tell him that the facts are really facts and the laws are really laws when we see them on the Christian position. ${ }^{57}$ Indeed, it is difficult, so the following discussion will be an example of the Van Tillian argument in which I try to apply it to the idea of God and the uniformity in Islam.

\section{An Example of Argument: Defending Christian God to Muslims}

Frame argues that Van Til maintains negative argument in his apologetics rather than positive, for instance, maintaining the world as unintelligible if God does not exist rather than making a positive claim such as if the world is intelligible, God must exist (the latter is utilized by classical apologists). For Frame, when someone applies this method to Muslims who believe in a Unitarian God, he needs both negative and positive arguments. ${ }^{58}$ We have no room to discuss this issue here, and I prefer to use both negative and positive claims in the following example. The rest of the discussion will be: 1) Stating the Islam view on God (Allah) and its uniformity worldview, 2) reducing its claim to unintelligible (reductio ad absurdum), and 3) maintaining the intelligible of the Trinity and the Christian worldview.

Islam worldview has a uniformity characteristic, for instance, how to pray (doing salat), read the Quran, fasting etc., are the same for all Muslims

\footnotetext{
56 Van Til, Christian Apologetics, 129.

57 Ibid.

58 Frame, Cornelius Van Til, 318-19.
} 
in all places. ${ }^{59}$ Indeed, it is heavily influenced by its concept of God which has a Unitarian characteristic. Zulkiple Abd. Ghani's article is probably a good example to explain the relation between Islam concept of God and its idea of uniformity. This article deals with the uniformity of Muslim's broadcast media in this era of globalization. Regarding the definition of the Muslim media, Ghani argues:

..., Muslim media or Islamic media refers to media that is operated based on the concept of tawhid (Unity of God) in its philosophy and follow the rule of syariah (God's rule and law) in its activities. The objectives of the media, its contents and ethics employed, and commitment to Islam may be used to determine the Islamicity of Muslim media (Zulkiple Abd. Ghani 2006). ${ }^{60}$

The phrases "tawhid in its philosophy" and "Islamicity of Muslim media" are worth to be noticed, and the quotation above could be meant: The concept of the unity of God (tawhid) in its philosophical aspect - which implies his singleness without personal plurality - must become the base of the "Islamicity" (uniformity) of the Islam media. My interpretation here is probably overemphasized yet it could give a glimpse of understanding on the relation between the Islam concept of Unitarian God and the idea of uniformity. Nevertheless, I have a substantial reason to maintain the relation between the two. Speaking about the Unitarian concept of God in Islam, Muslims have no ultimate point of reference on how the one and the many connect to each other and therefore they have no base and example to apply this principle in life. The result is either maintaining the concept of one without plurality on one pole or having a difficulty to bring the many into

59 However, some divergences could be happened especially in those sectarian streams, for instance Ahmadiyya. And indeed, how to pray and fasting, for instance, do not have to the same in details for all but their essence must be practiced in all places, such as, they must doing salat with Mecca as the direction and five times a day, and fasting during the Ramadan month and not in the other months.

${ }^{60}$ Zulkiple Abd. Ghani, "The Uniformity of Broadcast Media in the Muslim World During the Age of Globalization," Islamiyyat 33 (2011): 54. 
unity on the other pole. We could think an example for the first pole, such as, doing salat in a certain way without any alternative, and for the second pole, the diversity of the domains of life are Islamized, such as, Islamic state, sharia bank, sharia law in public domain etc. Indeed, Christianity, especially in its Reformed wing, does not know Christianization, but Christians who work in all areas of life for the glory of God.

To elaborate more on Islam God, emphasizing the supremacy of the only one God (Allah) or the doctrine of tawhid is central in Muhammad's teaching. ${ }^{61}$ The credo, "there is no god but Allah" is the highest confession. ${ }^{62}$ Also, the singleness of Allah is the particular attribute of his Godhead which has to become the main focus of Muslims' faith. ${ }^{63}$ However, this conviction is not the same with the Christian concept of the oneness of God. Islam idea implies that there are no plurality in God's personality and therefore people could say that the concept of the absolute monotheism in the Quran is an antithesis of the Christian monotheistic view on God, namely, the Trinitarian monotheistic God. ${ }^{64}$ Following this idea, to associate partners with Allah is to commit idolatry and is regarded by Muslims as the unpardonable sin. ${ }^{65}$ Consequently, the Christian teaching on Jesus Christ as the Son of God who is equal with God the Father is regarded as a blasphemy. The Quran declares, "Never has Allah begotten a son, nor is there any other god besides him... He that invokes another God besides Allah - a god of whose divinity he has no proof - his Lord will bring him to account. ${ }^{66}$

\footnotetext{
61 Cf. A. S. Tritton, Islam: Belief and Practices (New York: Hutchinson's University Library, 1951), 10.

62 Ibid., 42.

63 Cf. L. Gardet, "Allāh" in The Encyclopedia of Islam: New Edition, Vol. 1, H.A.R. Gibb et al., eds. (Leiden: Brill, 1979), 407.

64 Cf. Timothy C. Tennet, Christianity at the Religious Roundtable: Evangelicalism in Conversation with Hinduism, Buddhism, and Islam (Grand Rapids: Baker Academic, 2002), 145.

65 Ibid., 146.

66 Ibid.
} 
Having such idea of God, Muslims are against to the doctrine of the incarnation (God takes for himself human nature), and therefore it is reasonable to say that Islam has no idea of translation and contextualization. That is why, the Quran cannot be translated into other languages ${ }^{67}$ and Islam teachings are not allowed to be contextualized. ${ }^{68}$ All divergent practices are considered as heresy, for instance, when an Indonesian Muslim prays (doing salat) and makes the east (e.g. Papua New Guinea) his direction rather than the west which directs to Meca, this practice is considered as a blasphemy. This uniformity principle influences all areas of Muslims' life and we could say that it colors their worldview.

Indeed, the idea of God as one without personal distinctions and the idea of uniformity have some difficulties. In general, the idea of one without diversity is impossible. For instance, if all men in this planet just have the same face, the same color, and the same size we cannot make distinctions among each other and therefore we never know with whom we speak and make a relationship. If all is the same, relation and meaning will become impossible. Rushdoony is correct when he argues that the existence of meaning needs differences and particularities. If day and night are one, good and evil are one, life and death are one then meaning is impossible. ${ }^{69}$

It is also true when we applied it to Islam $\operatorname{God}^{70}$ who has no plurality in his personality. For instance, if this God is just one without personal

67 Indeed, the Quran has been translated into other languages, for instance, Indonesian, but it cannot be an authoritative Quran, and that is why every Muslim have to read the Quran in its Arabic language.

68 In my opinion, translation and contextualization are interdependent terms especially in the Christian context, for translation is an effort to translate a text into a new language in order to be understood by the people who speak in that language without changing its meaning, while contextualization is an effort to make the translated text can be well received within the context of those people. For this reason, it is correct to say that because Islam idea does not know the principle of translation, thus contextualization is not relevant for Muslims.

69 Rousas John Rushdoony, "The One and Many Problem - Contribution of Van Til," in Jerusalem and Athens, E.R. Geehan, ed. (Phillipsburg: P\&R, 1980), 339.

70 Indeed, it is not easy to say that a Unitarian God will exclude all distinctions, because as a 
distinctions, then relationship, mind, and consciousness cannot exist in him. Relationship (e.g. love relationship) absolutely needs other person to be an object whom the subject relates himself. Concerning the mind, its existence depends on the existence of subject and object. In a God who has no distinctions (e.g. personal distinctions) in himself, there is no object to be contemplated, and when there is no object to be contemplated, the mind will become blank. The same principles is maintained by Shedd when he speaks about consciousness. He describes:

All consciousness implies of subject and object: a subject to know and an object to be known. If there be a subject but no object, consciousness is impossible. And if there be an object but no subject, there can be no consciousness. Mere singleness is fatal to consciousnes. I cannot be conscious of a thing unless there is a thing to be conscious of. Take away all object of thought, and I cannot think. ${ }^{71}$

In this respect, the condition for the existence of relationship, mind, and consciousness is impossible in such God, and hence speaking about his attributes as loving God, omniscience, omnipresence, etc. has a considerable problem.

And regarding the uniformity, I put here a very simple example, suppose a Muslim went astray in a big jungle without signposts and a compass, it was impossible for him to do his salat (prayer) because he did not know the east and the west. Moreover, the idea of uniformity potentially

person, this God will imply a plurality in its characteristics or attributes. However, all attributes of a certain person could only be manifested in his relationship to other person or object. For instance, one's mind comes into exist through its relationship with persons or objects outside, otherwise it will be blank. This is also true for a person's moral qualities, such as, love, wisdom, knowledge, etc., which need objects in order not to become a mere blank love, wisdom, and knowledge. Thus, this is the complicated problem of the concept of the Unitarian God.

71 William G. T. Shedd, Dogmatic Theology (Grand Rapids: Zondervan Publishing House, 1969), 169. 
has a great danger to compel someone to act in a superficial way and also bringing out religious radicalism as well as legalism. ${ }^{72}$

On the contrary, the Christian God (the Trinity) is very intelligible, for instance, because he is one and has different personalities (diversity) then a love relationship among the persons could be happened, and also the existence of mind and consciousness become possible because a certain person in the Trinity has other persons to become the objects of contemplating. Moreover, the Trinitarian principle of unity and diversity (one and many) makes the Christian life intelligible. For example, a Christian can pray whenever and wherever (even when a Christian went astray in a big jungle) as long as he prays to the Father, through the name of the Son, and led by the Holy Spirit. Time, place, and the style of prayer are considered as the domain of the diversity, and praying to the Father, through the Son, and in the Holy Spirit are considered as the area of the unity. Is not this reasonable and does not this make us free?73

72 The Jews in the time of Jesus performed this characteristic and therefore Jesus criticized them by saying, "Woe unto you, scribes and Pharisees, hypocrites! for ye compass sea and land to make one proselyte, and when he is made, ye make him twofold more the child of hell than yourselves" (Matt. 23:15 - KJV). The spirit of superficiality, legalism, and religious radicalism in the Jews history reached its peak through the crucifixion of Jesus Christ.

73 As an additional footnote, it is probably possible for the Muslims to construct their own presuppositional system based on their understanding on a Unitarian God. And perhaps, disputing with Darwinistic Naturalists which believe "time plus chance plus matter" and "the natural selection" as substantial for the origin of the species will be productive. One can guest that Muslims will have intelligible arguments because they have an ultimate point of reference, namely, God. However, I think, they really find problems on how this God could become an adequate ultimate point of reference in their system metaphysically, epistemologically, and morally, such as, speaking about relationship, meaning, consciousness, mind, and how to put the many into one and to see the one into many, etc. 